\title{
Assignment of ATCC 27377 to Planctomyces staleyi sp. nov. and Conservation of Pasteuria ramosa Metchnikoff 1888 on the Basis of Type Descriptive Material

\author{
Request for an Opinion
}

\author{
MORTIMER P. STARR, ${ }^{1 *}$ RICHARD M. SAYRE, ${ }^{2}$ AND JEAN M. SCHMIDT ${ }^{3}$ \\ Department of Bacteriology, University of California, Davis, California $95616^{1}$; Nematology Laboratory, \\ Beltsville Agricultural Research Center (West), U.S. Department of Agriculture, Beltsville, Maryland 20705 $5^{2}$ \\ and Department of Botany and Microbiology, Arizona State University, Tempe, Arizona $85287^{3}$
}

The name Pasteuria ramosa Metchnikoff 1888 is used for two quite different kinds of bacteria. We request that the Judicial Commission issue an Opinion to the effect that the name be used only for the sort of bacterial parasite or endosymbiont described by Metchnikoff from the body cavities of cladoceran invertebrates belonging to the family Daphnidae. The name should not be used for an organism quite different from that described by Metchnikoff, ATCC $27377^{\mathrm{T}}$, a member of morphotype IV of the Blastocaulis-Planctomyces group of budding and nonprosthecately appendaged bacteria, for which we propose the name Planctomyces staleyi sp. nov. We further recommend that relevant alterations be made in connection with the Approved Lists of Bacterial Names and culture collection catalogs.

Background information. In 1888, Metchnikoff (7) illustrated the developmental stages of a bacterial parasite he had discovered in the body cavities of the cladoceran invertebrates Daphnia pulex and D. magna. Although he did not succeed in isolating the bacterium, he described it quite adequately by the standards common a century ago and named it Pasteuria ramosa (gen. nov., sp. nov.). Some subsequent efforts to find an organism identical to that described by Metchnikoff have led to confusion with a rather different bacterium, and both are now called Pasteuria ramosa Metchnikoff $1888(7,15)$. One is the bacterium parasitic or endosymbiotic in cladocerans, seemingly identical to the Daphnia organism of Metchnikoff, which has in recent years been rediscovered and described in detail $(8-10)$. Efforts to isolate this cladoceran parasite in axenic culture are under way (R. L. Gherna and R. M. Sayre, in progress).

The other kind of organism to which the name was later applied homonymously is a group of nonparasitic budding bacteria, either free-living or attached to the external surfaces of Daphnia and other small invertebrates as well as to other plankton. Certain of these creatures share, perhaps superficially, some (but by no means all) of the properties described by Metchnikoff; some of these look-alikes have also been called Pasteuria ramosa Metchnikoff 1888. Among pertinent reports-which, it must be stressed, did not include attempts to search directly for Metchni- koff's organism in the body cavities of cladocerans-we might mention the findings of Henrici and Johnson (2) concerning a free-living aquatic bacterium which reproduced by budding. Suggesting that the "spore bodies" illustrated by Metchnikoff were not spores but buds, Henrici and Johnson ignored Metchnikoff's Daphnia parasite but used its name (Pasteuria ramosa Metchnikoff 1888) for certain of the free-living budding and appendaged bacteria they did find. (Zavarzin [19] took exception to this interpretation of Metchnikoff's paper by Henrici and Johnson [i.e., that the "spore bodies" were buds], pointing out it was unlikely that a scientist of Metchnikoff's capability would have confused spore formation with the budding process; $\mathrm{Za}$ varzin's view has been challenged [15], but recent work [9] has supported it.)

More recently, Hirsch $(3,4)$ equated with Metchnikoff's organism a budding bacterium he had found attached externally to the antennae of Daphnia. Hirsch's organism (3) had some properties reminiscent of those described by Metchnikoff for certain developmental stages of the Daphnia parasite; however, as later events demonstrated, it was an organism rather different from that of Metchnikoff, being a budding bacterium resembling those that Henrici and Johnson (2) had studied but living externally on Daphnia. Hirsch $(3,4)$ followed Henrici and Johnson's infelicitous nomenclatural action of retaining the name (Pasteuria ramosa) Metchnikoff had used 
for the Daphnia parasite but restricting this name only to these quite different budding and nonparasitic forms. Budding bacteria, probably similar to those studied by Henrici and Johnson (2) and by Hirsch (3), were observed by Staley (15) attached to other aquatic microorganisms, including the carapaces of Daphnia. Staley isolated such organisms from aquatic habitats in Michigan and California and referred them to the Pasteuria-Blastobacter group $(14,15)$. A culture of one of these budding bacteria was deposited in the American Type Culture Collection (ATCC) as the type strain of Pasteuria ramosa Metchnikoff 1888 under accession number ATCC 27377 (1, 15).

One could argue that the actions up to this point (in the early 1970s) might have been weakly justified by the superficial resemblance of the free-living (or, at least, nonparasitic) organisms described by Henrici and Johnson (2), Hirsch (3, 4), and Staley (15) to some of the developmental stages of the Daphnia parasite as described by Metchnikoff (7). However, by 1980 , when this particular strain (ATCC 27377) was designated in the Approved Lists of Bacterial Names (14) as the type strain of Pasteuria ramosa Metchnikoff 1888 , the nonequivalence should have been evident because modern papers on the cladoceran parasite (Metchnikoff's Pasteuria ramosa) had appeared during the $1970 \mathrm{~s}(8,10)$, before the Approved Lists went to press. These papers, and an even more recent one (9), demonstrate unequivocally that an organism identical to that described by Metchnikoff (7), but quite different from the free-living budding forms $(2,3,15)$, really exists.

Moreover, from a series of studies $(11-13,18)$ on organisms of the sort represented by ATCC $27377^{\mathrm{T}}$, as well as that very strain, it is now quite clear that ATCC $27377^{\mathrm{T}}$ is a typical member of morphotype IV of the Blastocaulis-Planctomyces group of budding and nonprosthecately appendaged bacteria (18). ATCC $27377^{\mathrm{T}}$ bears little relationship to Metchnikoff's organism (7); the unrelatedness becomes even more evident from scrutiny of the modern characterizations of the cladoceran parasite (8-10). ATCC 27377 is an inappropriate type strain for Pasteuria ramosa Metchnikoff 1888 . The problem of homonymy does not formally disappear by calling ATCC $27377^{\mathrm{T}}$ "Pasteuria ramosa sensu Staley", (17); however, when it is viewed solely as a trivial name, this designation does at least have the advantage of distinguishing between two different organisms both named Pasteuria ramosa.

The overall nomenclatural confusion-including homonymy and designation of improper type material-requires the assignment of ATCC $27377^{\mathrm{T}}$ to a more appropriate taxon as well as the judicial intervention and other actions proposed herein.

Assignment of ATCC $27377^{\mathrm{T}}$ to the genus Planctomyces. To propose new generic taxa before completion of the relevant portions of our extensive comparative studies on some 40 strains belonging to the Blastocaulis-Planctomyces group (M. P. Starr and J. M. Schmidt, manuscript in preparation) would be premature $(11,12)$. Moreover, basing new taxa in this bacterial group (or any other, for that matter) on only one or two strains is not a sound taxonomic practice. However, to have the accompanying Request for an Opinion considered on an adequate basis, we were urged (W. E. C. Moore, personal communication) to recommend assignment of ATCC $27377^{T}$ to a definite taxon in the present paper. Under these circumstances, the action currently most appropriate in our view was to name ATCC $27377^{\mathrm{T}}$ as a new species of the genus Planctomyces, on the basis that ATCC $27377^{\mathrm{T}}$ does fit the present definition of the genus Planctomyces $(5,12,17)$. When our comprehensive examination of the entire group is completed, this organism may be transferred to a different genus (12).

In its present meaning $(5,12,17)$, the genus Planctomyces is quite heterogeneous. It contains two validly published species, Planctomyces bekefii (the type species of the genus) and Planctomyces maris, and a number of irregular "species" $(5,12)$. To the extent determinable in the absence of axenic cultures of Planctomyces bekefii (12), these two valid species (as well as many of the irregular ones) are probably sufficiently unrelated $(11,12)$ to warrant eventual placement in different genera. ATCC $27377^{\mathrm{T}}$ differs substantially from both of these Planctomyces species; albeit our present impression is that ATCC $27377^{\mathrm{T}}$ is taxonomically closer to Planctomyces maris than to Planctomyces bekefii. Taking all of these factors into account, we now formally propose assignment of ATCC $27377^{\mathrm{T}}$ to Planctomyces staleyi sp. nov., with ATCC 27377 as the type strain.

Emended description of Planctomyces staleyi sp. nov. Planctomyces staleyi has been described previously by Staley $(15,16)$ under the name Pasteuria ramosa Metchnikoff 1888 , with ATCC 27377 as its type strain. We wish now only to make the following alterations in those published descriptions, based mainly on our findings by the methodologies we usually employ (11-13).

Planctomyces staleyi sp. nov. (M. L. adj.; sta'ley.i.), named in honor of James T. Staley, imaginative and industrious isolator of unusual bacteria, including ATCC $27377^{\mathrm{T}}$ (15).

Synonyms: Pasteuria ramosa sensu Staley $(15,16)$. Morphotype IV (in part, at least) of the 


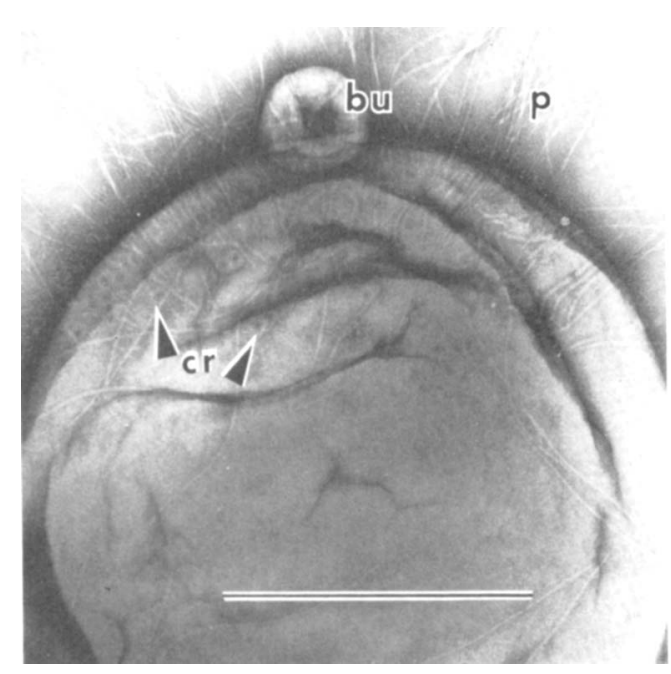

FIG. 1. Reproductive half of a cell of Planctomyces staleyi sp. nov., ATCC $27377^{\mathrm{T}}$, negatively stained with $1.0 \%$ uranyl acetate. $\mathrm{cr}$, Crateriform surface structures; bu, bud; p, pili. Bar, $0.5 \mu \mathrm{m}$.

Blastocaulis-Planctomyces group of budding and nonprosthecately appendaged bacteria (1113). Not Pasteuria ramosa Metchnikoff 1888 sensu stricto $(7,9,13,17)$.

The type strain of Planctomyces staleyi sp. nov. is ATCC 27377 (ICPB 2138; Staley "Michigan strain"). A putative reference strain, with which we have had considerable experience (13, 18 ), is ICPB 4362 (Schmidt strain CLPM, "white" clone derived from ICPB 4232; ATCC 35122).

ATCC $27377^{\mathrm{T}}$ was isolated from Lake Lansing, Michigan (15), and ICPB 4362 was isolated from Campus Lake, Louisiana State University, Baton Rouge $(13,18)$. Other populations of Planctomyces staleyi and close relatives also belonging to morphotype IV have been found by us in aquatic habitats the world over. These organisms are usually attached to filamentous algae and cyanobacteria by a holdfast located at the distal end of the fascicle (the multifibrillar major appendage, which is further considered below) or at the nonreproductive (nonbudding and nonpiliated; see below) pole of the cell, if a fascicle is not present.

Although occasional cells take the Gram stain, the reaction of Planctomyces staleyi is predominantly gram negative, as is to be expected from the gram-negative cell envelope profile of strains belonging to morphotype IV of the BlastocaulisPlanctomyces group (13); in those morphotype IV strains thus examined, no discrete peptidoglycan layer can be visualized in thin sections by transmission electron microscopy (13).

ATCC $27377^{\mathrm{T}}$, ICPB 4362 , and other strains belonging to morphotype IV (as well as strains belonging to other morphotypes) of the Blastocaulis-Planctomyces group are highly resistant to beta-lactam antibiotics (e.g., methicillin, penicillin $\mathrm{G}$, ampicillin, cephalosporin $\mathrm{C}$ ) and other inhibitors of peptidoglycan synthesis (e.g., vancomycin, bacitracin). Although ATCC $27377^{\mathrm{T}}$ has not yet been thus examined, the cell envelopes of other strains belonging to morphotype IV (and morphotype III) contained little or no muramic acid or diaminopimelic acid $(O$. Kandler, personal communication).

Planctomyces staleyi has numerous crateriform surface structures (11-13), a defining characteristic of the entire Blastocaulis-Planctomyces group. There are two kinds of crateriform structures in ATCC $27377^{\mathrm{T}}$; the larger ones (12$\mathrm{nm}$ diameter) are located on the reproductive (budding) pole of the cell, from which short and brittle pili (5- to 6-nm diameter) also extend (Fig. 1). Smaller crateriform or porelike structures (5to 7-nm diameter), which occur on the nonreproductive and nonpiliated pole of the cell opposite the budding site, are not as common in ATCC $27377^{\mathrm{T}}$ as in ICPB 4362 and other strains of Planctomyces staleyi (see Fig. 3E of reference 18).

Planctomyces staleyi forms a fragile fascicle (11-13), a bundled or braided multifibrillar appendage, originating from the nonreproductive and nonpiliated pole of the cell. The individual fibrils of the fascicle are about $3 \mathrm{~nm}$ in diameter and several micrometers in length. This fascicle, a third kind of nonprosthecate appendage (i.e., in addition to the sheathed flagellum of the swarmers and the short pili), is the least obvious appendage in axenic cultures of Planctomyces staleyi. Typical fascicles of ATCC $27377^{\mathrm{T}}$ are shown here in Fig. 2 and 3 ; the fascicle of another Planctomyces staleyi strain is illustrated elsewhere (see Fig. 4A of reference 18). Fascicles are very easy to overlook in transmission electron microscopic preparations of axenic cultures. They are seen more readily in natural material or laboratory enrichments of Planctomyces staleyi and other morphotype IV strains, in which they frequently terminate in a definite holdfast (as shown here in Fig. 4). The fascicles of ATCC $27377^{\mathrm{T}}$ in axenic culture are not only inconspicuous (Fig. 2), but also quite fragile (Fig. 3).

Planctomyces staleyi goes through a developmental cycle, which has been described elsewhere (18). The mature bud develops a sheathed flagellum attached near the piliated pole (opposite the fascicle origin) and becomes a swarmer; the swarmer loses its flagellum and becomes a sessile mother cell (with a distal holdfast and eventually a fascicle at the pole opposite the piliated and budding pole); the mother cell develops a bud; etc. 


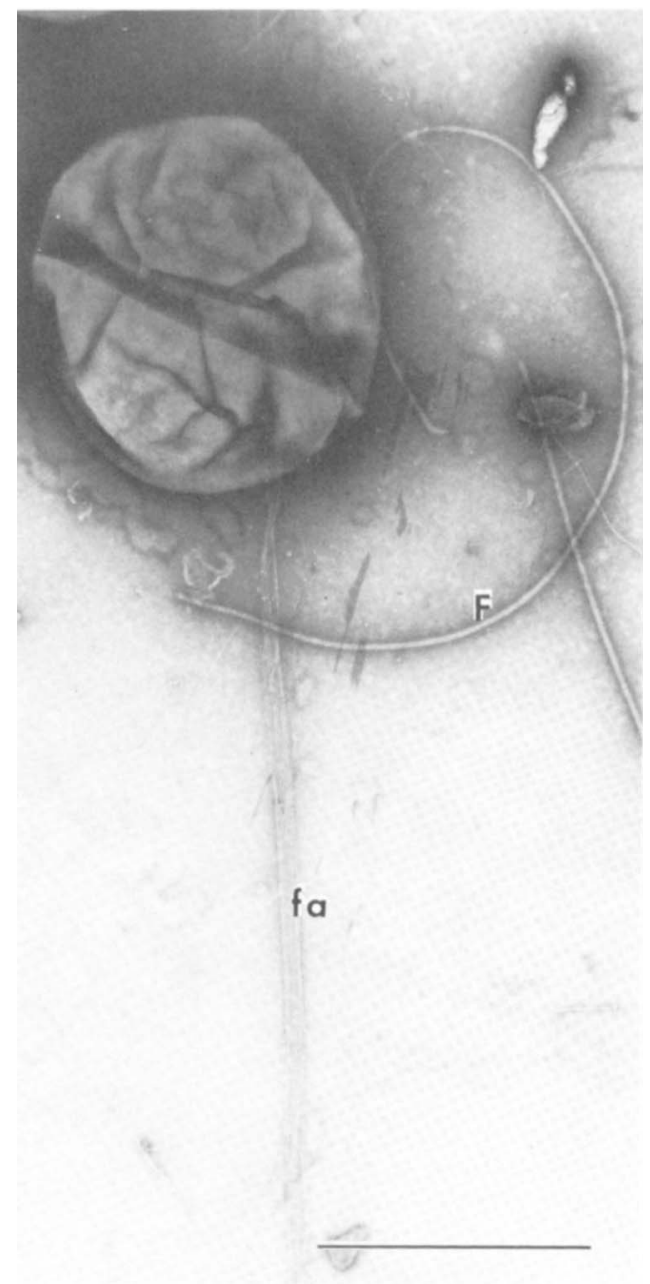

FIG. 2. Cell of Planctomyces staleyi sp. nov., ATCC $27377^{\mathrm{T}}$, negatively stained with $1.0 \%$ uranyl acetate. fa, Fascicle; F, sheathed flagellum. Bar, 0.5 $\mu \mathrm{m}$.

The guanine plus cytosine $(\mathrm{G}+\mathrm{C})$ content of the DNA of ATCC $27377^{\mathrm{T}}$ (M. Mandel, personal communication) is $59 \mathrm{~mol} \%$ by buoyant density (variance in four independent determinations was zero); the value reported elsewhere (15) for the same strain as analyzed by the same method and by the same analyst was $57 \mathrm{~mol} \% \mathrm{G}+\mathrm{C}$. The corresponding value for ICPB 4362 is $58 \mathrm{~mol} \%$ $\mathrm{G}+\mathrm{C}$ (M. Mandel, personal communication). Other strains belonging to morphotype IV (though not necessarily to Planctomyces staleyi) give values ranging from 56 to $63 \mathrm{~mol} \% \mathrm{G}+\mathrm{C}$ (M. Mandel, personal communication).

Request for an Opinion. After the present assignment of ATCC 27377 as the type strain of Planctomyces staleyi sp. nov., we request that the Judicial Commission issue an Opinion to conserve the name Pasteuria ramosa Metchnikoff 1888 on the basis of the original description by Metchnikoff (7) as emended by others in recent years (8-10).

There are several bases for this request. The name used by Metchnikoff for the cladoceran parasite is the senior homonym. The expedient assignment of a member of morphotype IV of the Blastocaulis-Planctomyces group as the type strain (of Pasteuria ramosa) in the $1980 \mathrm{Ap}-$ proved Lists of Bacterial Names (14) was counter to type material available in 1979 and

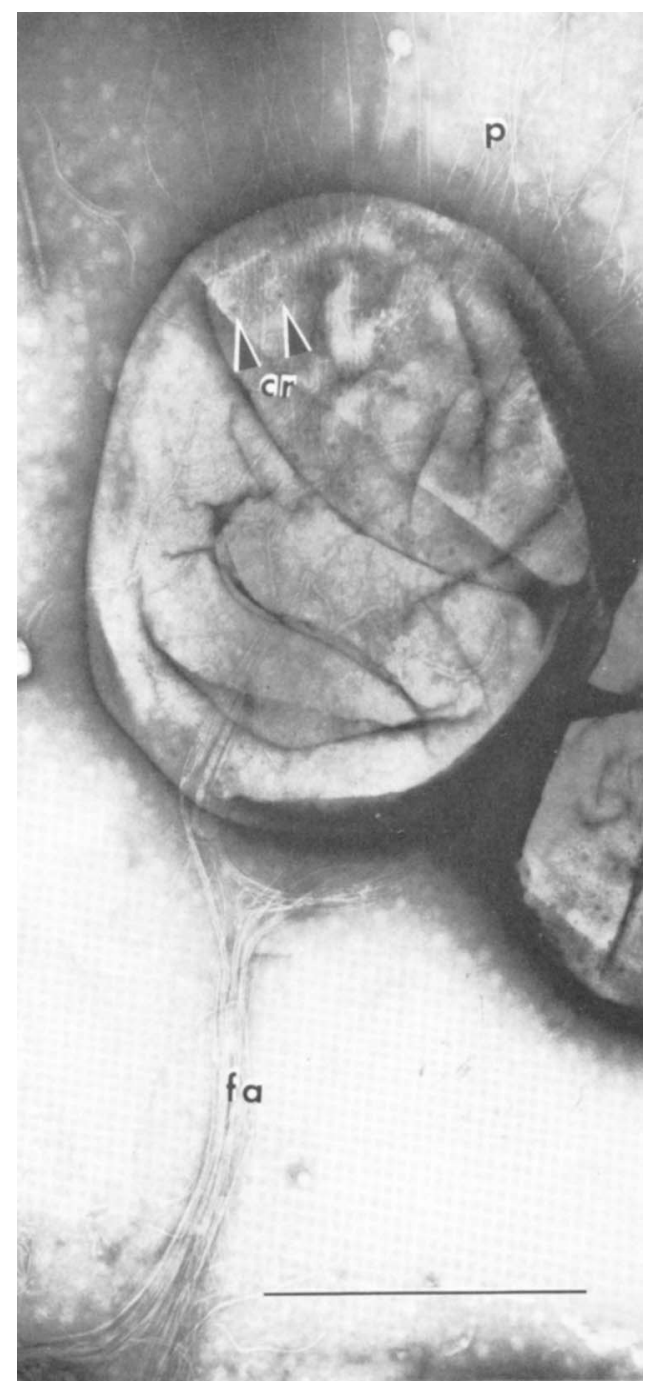

FIG. 3. Cell of Planctomyces staleyi sp. nov., ATCC $27377^{\mathrm{T}}$, negatively stained with $1.0 \%$ uranyl acetate, showing its fragile fascicle, the attachment of which to the cell is disrupted. fa, Fascicle; p, pili; cr, crateriform surface structures. Bar, $0.5 \mu \mathrm{m}$. 


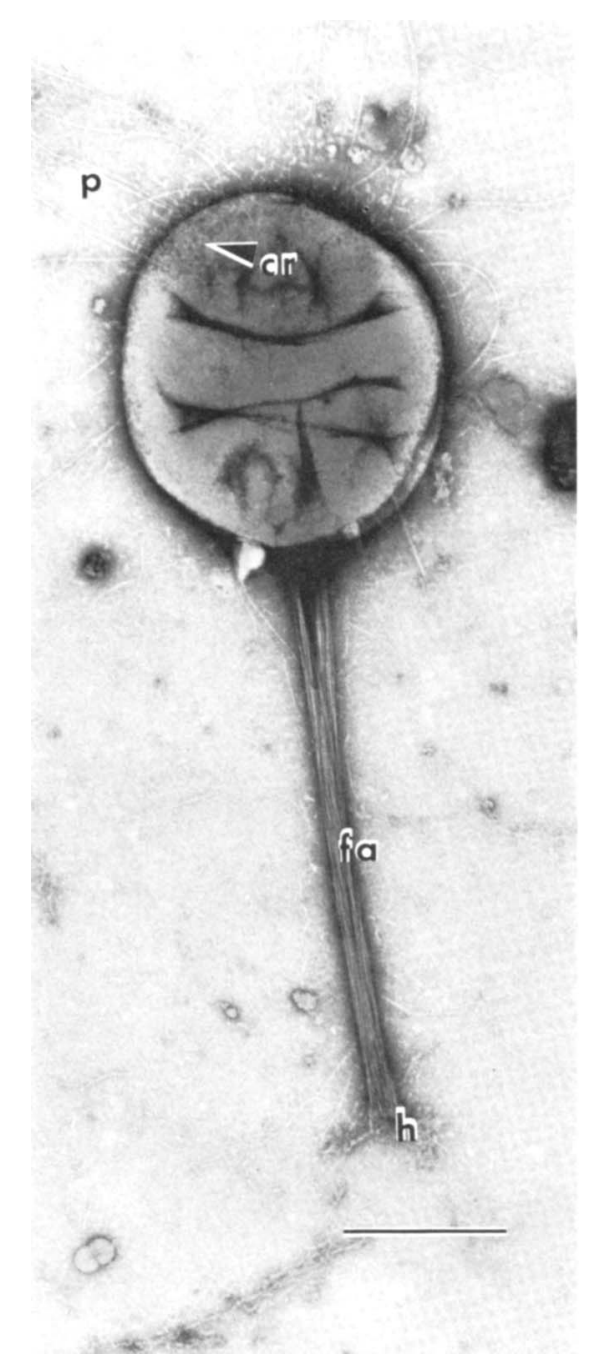

FIG. 4. Morphotype IV cell (either Planctomyces staleyi or a close relative) observed directly from an enrichment culture (11) prepared from a water sample collected in September 1982 from a lily pond in Burgers Park, Pretoria, South Africa. The cell was negatively stained with $1.0 \%$ uranyl acetate. The fascicle in this cell from a crude enrichment culture is much more conspicuous (and possibly also wider and composed of more fibrils) compared with the corresponding structures in cells from axenic cultures. fa, Fascicle; $h$, holdfast; p, pili; cr, crateriform surface structures. Bar, $0.5 \mu \mathrm{m}$.

has led to nomenclatural confusion that, in view of extensive historical interest in the species, would have continued as long as the name also was associated with the junior homonym. Perusal of provisions of the International Code of Nomenclature of Bacteria (6) regarding noncultivable bacteria leads to the conclusion that the type material for Pasteuria ramosa has been, since 1888 (7) and until the Approved Lists (14) was published in 1980, Metchnikoff's description and illustrations (7), enhanced by the modern descriptions and illustrations, especially the electron micrographs $(8-10)$. We request that this material be retained as the type material pending designation of a type strain if, as we hope, the natural material yields axenic cultures of Metchnikoff's Pasteuria ramosa (R. L. Gherna and R. M. Sayre, in progress, personal communication).

The Opinion would designate Metchnikoff's description and illustrations-as enhanced by modern descriptions $(8-10)$ of the cladoceran parasite-as the type material of Pasteuria ramosa Metchnikoff 1888, replacing ATCC 27377 as the type strain (14).

Although it is not in the purview of the Judicial Commission, accessioning information in culture collection records should be corrected to show the true nature of ATCC 27377 as the type strain of Planctomyces staleyi sp. nov. and as a representative of morphotype IV of the Blastocaulis-Planctomyces group of budding and nonprosthecately appendaged bacteria $(11-13,18)$.

\section{ACKNOWLEDGMENTS}

This work was supported in part by Public Health Service grant AI-08426 from the National Institutes of Health.

One of us (M.P.S.) acknowledges with thanks the warm hospitality provided (during a sabbatical leave when this paper was written) by the Department of Botany and Microbiology, Arizona State University, Tempe. We are grateful to $M$. Mandel for determinations of deoxyribonucleic acid base compositions and to $\mathrm{O}$. Kandler for determinations of cell envelope components.

\section{LITERATURE CITED}

1. Gherna, R. L., and P. Pienta (ed.). 1982. Bacteria and bacteriophages. Catalogue of strains I, 15th ed. American Type Culture Collection, Rockville, Md.

2. Henrici, A. T., and D. E. Johnson. 1935. Studies of freshwater bacteria. II. Stalked bacteria, a new order of Schizomycetes. J. Bacteriol. 30:61-93.

3. Hirsch, P. 1972. Re-evaluation of Pasteuria ramosa Metchnikoff 1888, a bacterium pathogenic for Daphnia species. Int. J. Syst. Bacteriol. 22:112-116.

4. Hirsch, P. 1974. Genus Pasteuria Metchnikoff 1888, 166, emend. mut. char. Hirsch 1971, 113, p. 158-159. In R. E. Buchanan and N. E. Gibbons (ed.), Bergey's manual of determinative bacteriology, 8th ed. The Williams \& Wilkins Co., Baltimore.

5. Hirsch, P., and H. Skuja. 1974. Genus Planctomyces Gimesi 1924, 4, p. 162-163. In R. E. Buchanan and N. E. Gibbons (ed.), Bergey's manual of determinative bacteriology, 8th ed. The Williams \& Wilkins Co., Baltimore.

6. Lapage, S. P., P. H. A. Sneath, E. F. Lessel, V. B. D. Skerman, H. P. R. Seeliger, and W. A. Clark (ed.). 1975. International code of nomenclature of bacteria. American Society for Microbiology, Washington, D.C.

7. Metchnikoff, E. 1888. Pasteuria ramosa. Un représentant des bactéries à division longitudinale. Ann. Inst. Pasteur (Paris) 2:165-171.

8. Sayre, R. M., J. R. Adams, and W. P. Wergin. 1979. Bacterial parasite of a cladoceran: morphology, develop- 
ment in vivo, and taxonomic relationships with Pasteuria ramosa Metchnikoff 1888. Int. J. Syst. Bacteriol. 29:252262.

9. Sayre, R. M., R. L. Gherna, and W. P. Wergin. 1983. Morphological and taxonomic reevaluation of Pasteuria ramosa Metchnikoff 1888 and "Bacillus penetrans" Mankau 1975. Int. J. Syst. Bacteriol. 33:636-649.

10. Sayre, R. M., W. P. Wergin, and R. E. Davis. 1977. Occurrence in Monia [sic] rectirostris (Cladocera: Daphnidae) of a parasite morphologically similar to Pasteuria ramosa (Metchnikoff 1888). Can. J. Microbiol. 23:15731579.

11. Schmidt, J. M., and M. P. Starr. 1978. Morphological diversity of freshwater bacteria belonging to the Blastocaulis-Planctomyces group as observed in natural populations and enrichments. Curr. Microbiol. 1:325-330.

12. Schmidt, J. M., and M. P. Starr. 1981. The BlastocaulisPlanctomyces group of budding and appendaged bacteria, p. 496-504. In M. P. Starr, H. Stolp, H. G. Trüper, A. Balows, and H. G. Schlegel (ed.), The prokaryotes. A handbook on habitats, isolation, and identification of bacteria. Springer-Verlag, Berlin.

13. Schmidt, J. M., and M. P. Starr. 1982. Ultrastructural features of budding cells in a prokaryote belonging to morphotype IV of the Blastocaulis-Planctomyces group. Curr. Microbiol. 7:7-11.

14. Skerman, V. B. D., V. McGowan, and P. H. A. Sneath 1980. Approved lists of bacterial names. Int. J. Syst. Bacteriol. 30:225-420.

15. Staley, J. T. 1973. Budding bacteria of the PasteuriaBlastobacter group. Can. J. Microbiol. 19:609-614.

16. Staley, J. T. 1981. The genus Pasteuria, p. 490-492. In M. P. Starr, H. Stolp, H. G. Trüper, A. Balows, and H. G. Schlegel (ed.), The prokaryotes. A handbook on habitats, isolation, and identification of bacteria. Springer-Verlag, Berlin.

17. Staley, J. T., P. Hirsch, and J. M. Schmidt. 1981. Introduction to the budding and/or appendaged bacteria, $\mathrm{p}$. 451-455. In M. P. Starr, H. Stolp, H. G. Trüper, A. Balows, and H. G. Schlegel (ed.), The prokaryotes. A handbook on habitats, isolation, and identification of bacteria. Springer-Verlag, Berlin.

18. Tekniepe, B. L., J. M. Schmidt, and M. P. Starr. 1981 Life cycle of a budding and appendaged bacterium belonging to morphotype IV of the Blastocaulis-Planctomyces group. Curr. Microbiol. 5:1-6.

19. Zavarzin, G. A. 1961. Budding bacteria. Mikrobiologia (English translation of Mikrobiologiya) 30:774-791. 